\title{
PENGARUH KUALITAS PELAYANAN FRONTLINER TERHADAP KEPUASAN NASABAH PADA BANK BNI SYARIAH KCP KARTINI -DEPOK
}

\author{
${ }^{1)}$ Muhlis, ${ }^{2)}$ Haryani \\ ${ }^{1)}$ Dosen Program Studi Manajemen, STIE Dewantara \\ J1. Raya Pemda Bojong Depok Baru III, Karadenan, Cibinong, Bogor, Jawa Barat 16913,Indonesia \\ Email: muhlis@dewantara.ac.id \\ ${ }^{2)}$ Alumni Program Studi Manajemen, STIE Dewantara \\ Jl. Raya Pemda Bojong Depok Baru III, Karadenan, Cibinong, Bogor, Jawa Barat 16913, Indonesia \\ Email: hanni.adheeva20@gmail.com
}

\begin{abstract}
The purpose of this study was to determine how much the physical service variable, reliability, responsiveness, assurance and empathy affect customer satisfaction at BNI Syariah KCP Kartini. This study uses a questionnaire as an instrument to take a sample of 100 respondents, who are BNI Syariah KCP Kartini Depok customers. The results of data analysis using multiple linear regression showed that partially, just empathy had a positive and significant effect on customer satisfaction at BNI Syariah KCP Kartini. Simultaneously note that F statistic > F table so that $\mathrm{Ho}$ is rejected, meaning that together physical evidance, reliability, responsiveness, assurance and empathy affect satisfaction customer. The independent variable can explain the dependent variable that is customer satisfaction by $39.6 \%$ and the remaining 60.4 is explained by other variables not included in this analysis.
\end{abstract}

Keywords: Physical Evidance, Reliability, Responsiveness, Assurance, And Empathy.

\begin{abstract}
ABSTRAK
Tujuan Penelitian ini adalah untuk mengetahui seberapa besar variabel pelayanan wujud fisik, kehandalan, daya tanggap, jaminan dan empati mempengaruhi kepuasan nasabah pada Bank BNI Syariah KCP Kartini. Penelitian ini menggunakan kuesioner sebagai instrument untuk mengambil sampel sebanyak 100 orang responden, yang merupakan nasabah BNI Syariah KCP Kartini Depok. Hasil analisis data dengan menggunakan regresi linier berganda menunjukan bahwa secara parsial hanya empati berpengaruh secara positif dan signifikan terhadap kepuasan nasabah di BNI Syariah KCP Kartini. Secara simultan diketahui bahwa F statistik > F tabel sehingga Ho ditolak, artinya secara bersama-sama wujud fisik, kehandalan, daya tanggap, jaminan dan empati berpengaruh terhadap kepuasan nasabah. Variabel independent mampu menjelaskan variabel dependen yaitu kepuasan nasabah sebesar 39.6\% dan selebihnya 60.4 dijelaskan oleh variabel lain yang tidak termasuk dalam analisa ini.
\end{abstract}

Kata kunci: Wujud Fisik, Kehandalan, Daya Tanggap, Asuransi, Empati.

\begin{tabular}{ll}
\hline 1. PENDAHULUAN & bersaing dengan bank lain. Tujuan dalam \\
1.1 Latar Belakang & persaingan tersebut adalah untuk \\
Dalam era globalisasi ini persaingan & mempertahankan nasabah dan merebut \\
industri keuangan perbankkan sangat & nasabah bank lainnya. Langkah yang \\
bersaing, baik di pasar domestik maupun di & dilakukan perbankan adalah bersaing dalam \\
pasar internasional. Untuk menghadapi & produk yang dijualnya dan bersaing dalam \\
persaingan tersebut mengharuskan pada & bentuk pelayanan terhadap nasabah dan \\
pihak manajemen bank berlomba dalam & calon nasabah. Dengan persaingan dalam
\end{tabular}


bentuk pelayanan bertujuan untuk menjadikan nasabah yang loyal terhadap bank tersebut. Salah satu bank yang ikut andil dan meramaikan dunia perbankan di Indonesia yaitu Bank Negara Indonesia (BNI) Syariah dan salah satu adalah BNI Syariah KCP Kartini Depok. Berdasarkan jumlah nasabah di BNI syariah KCP Kartini tahun 2016-2018.

Tabel 1. Data Nasabah di BNI syariah KCP Kartini Tahun 2016 - 2018

\begin{tabular}{|c|c|c|c|}
\hline & 2016 & 2017 & 2018 \\
\hline $\begin{array}{c}\text { Total } \\
\text { Nasabah }\end{array}$ & 1229 & 1009 & 1570 \\
\hline
\end{tabular}

(Sumber : Data Sekunder BNI Syariah KCP Kartini,2018)

Jika dilihat dari total pada tahun 2018 terjadi peningkatan yang sangat signifikan sebesar 56\% dari tahun sebelumnya. Pengingkatan yang signifikan ini harus ditindaklanjuti oleh peningkatan pelayanan, karena nasabah merupakan kunci suksesnya perbankan. Salah satu bagian diperbankan yang selalu berhadapan dengan nasabah adalah bagian frontliner, bagian ini terdiri dari teller, customer service dan security. Berdasarkan latar belakang tersebut maka perlunya diteliti pengaruh kualitas pelayanan frontliner terhadap kepuasan nasabah.

\subsection{Perumusan Masalah}

Berdasarkan permasalahan yang telah disebutkan diatas, maka penulis membuat perumusan masalah sebagai berikut :

1. Bagaimana pengaruh bukti fisik frontliner terhadap kepuasan nasabah Bank BNI Syariah KCP Kartini Depok?

2. Bagaimana pengaruh kehadalan frontliner terhadap kepuasan nasabah Bank BNI Syariah KCP Kartini Depok?
3. Bagaimana pengaruh daya tanggap frontliner terhadap kepuasan nasabah Bank BNI Syariah KCP Kartini Depok?

4. Bagaimana pengaruh jaminan frontliner terhadap kepuasan nasabah Bank BNI Syariah KCP Kartini Depok?

5. Bagaimana pengaruh empati frontliner terhadap kepuasan nasabah Bank BNI Syariah KCP Kartini Depok?

6. Bagaimana pengaruh Apakah kualitas pelayanan frontliner simultan terhadap kepuasan nasabah di Bank Syariah KCP Kartini Depok?

\subsection{Tujuan Penelitian}

Dalam penelitian ini, tujuan yang ingin dicapai adalah sebagai berikut :

1. Untuk mengetahui pengaruh bukti fisik frontliner terhadap kepuasan nasabah Bank BNI Syariah KCP Kartini Depok.

2. Untuk mengetahui pengaruh kehandalan frontliner terhadap kepuasan nasabah Bank BNI Syariah KCP Kartini Depok.

3. Untuk mengetahui pengaruh daya tanggap frontliner terhadap kepuasan nasabah Bank BNI Syariah KCP Kartini Depok.

4. Untuk mengetahui pengaruh jaminan frontliner terhadap kepuasan nasabah Bank BNI Syariah KCP Kartini Depok.

5. Untuk mengetahui pengaruh empati frontliner terhadap kepuasan nasabah Bank BNI Syariah KCP Kartini Depok.

6. Untuk mengetahui pengaruh kualitas pelayanan frontliner terhadap kepuasan nasabah Bank BNI Syariah KCP Kartini Depok.

\section{TINJAUAN PUSTAKA}

\subsection{Landasan Teori}

Kualitas menurut Juran (1962) adalah kesesuaian dengan manfaatnya, Crosby 
(1979) kesesuaian dengan kebutuhan yang meliputi evailability, delivery, reliability, maintainability dan cost effectiveness. Sedangkan menurut Deming (1982) kualitas harus bertujuan memenuhi kebutuhan pelanggan sekarang dan di masa datang. Gaspersz (1997) menyebutkan karakteristik yang unik dalam pelayanan diantaranya sebagai berikut:

1. Terdapat hubungan yang erat dengan pelanggan melalui proses pelayanan

2. Pelanggn berpartisipasi dalam proses memberikan pelayanan

3. Keterampian personil diberikan secara langsung kepada pelanggan

4. Pengukuran efektivitas pelayanan bersifat subjektif

Zeithaml et al. (1990) menyebutkan lima dimensi kualitas pelayanan yaitu bukti fisik, kehadalan, daya tanggap, jaminan dan empati. Bukti fisik adalah bukti fisik dalam pelayanan seperti pelayanan fisik. Kehandalan adalah kemempuan mewujudkan pelayanan yang dijadikan seara akurat dan dapat diperaya. Dalam hal ini perusahaan jasa memberikan pelayanan yang tepat, cepat dan menghargai semua pihak.

Daya tanggap adalah keinginan atau kesiapan karyawan atau pegawai untuk memberikan pelayanan. Jaminan berhubungan dengan dimensi pengetahuan, kompetensi, kesopanan dan kemampuan memberikan pelayanan yang jujur, meyakinkan dan terpecaya. Empati adalah kualitas pelayanan dalam hal perhatian yang diberikan oleh pemberi jasa kepada penerima jasa.

Schneider dan Bowen

menyebutkan bahwa pimpinan atau manager sangat sulit dalam mensupervisi secara langsung pada karyawan ketika mereka sedang berinteraksi dengan pelanggan, karena akan mempengarui kebebasan pelayanan.

Menurut Kottler (2004), kepuasan pelanggan adalah perasaan senang atau kecewa seseorang yang muncul sebagai hasil dari perbandingan antara kinerja (hasil) produk yang dipikirkan terhadap kinerja atau hasil yang diharapkan. Jika kinerja dibawah harapan, maka pelanggan akan merasa tidak puas. Jika kinerja memenuhi harapan, maka pelanggan akan merasa puas dan jika kinerja melebihi harapan pelanggan akan merasa sangat puas.

\section{Tabel 2. Definisi Operasional}

\begin{tabular}{|c|c|}
\hline Variabel & Indikator \\
\hline $\begin{array}{l}\text { Bukti } \\
\text { Fisik }\end{array}$ & $\begin{array}{l}\text { 1. penampilan fisik frontliner } \\
\text { 2. kelengkapan atribut } \\
\text { frontliner } \\
\text { 3. penggunaan grooming/ } \\
\text { make up frontliner } \\
\text { pemberian layanan yang } \\
\text { ramah kepada nasabah }\end{array}$ \\
\hline $\begin{array}{l}\text { Kehan- } \\
\text { dalan }\end{array}$ & 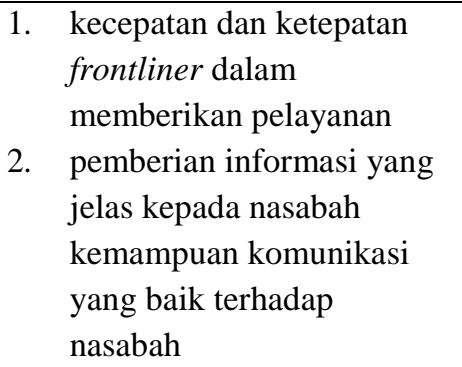 \\
\hline $\begin{array}{l}\text { Daya } \\
\text { tanggap }\end{array}$ & $\begin{array}{l}\text { 1. } \begin{array}{l}\text { kecepatan frontliner dalam } \\
\text { memberikan solusi } \\
\text { terhadap permasalahan } \\
\text { nasabah }\end{array} \\
\text { 2. pemahaman frontliner } \\
\text { dalam memahami } \\
\text { kebutuhan nasabah } \\
\text { kemudahan dalam } \\
\text { pemberian layanan }\end{array}$ \\
\hline Jaminan & $\begin{array}{ll}\text { 1. } & \text { pemberian rasa aman } \\
\text { kepada nasabah dalam } \\
\text { bertransaksi } \\
\text { 2. } \\
\text { frontliner menguasai } \\
\text { pengetahuan produk } \\
\text { sehingga mampu menjawab } \\
\text { pertanyaan nasabah }\end{array}$ \\
\hline Empati & 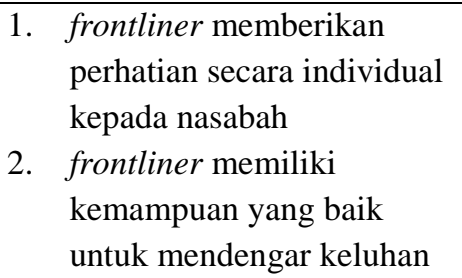 \\
\hline
\end{tabular}




\begin{tabular}{|c|c|c|}
\hline & & $\begin{array}{l}\text { nasabah dan memberikan } \\
\text { solusi alternative } \\
\text { pemberian apresiasi kepada } \\
\text { nasabah }\end{array}$ \\
\hline $\begin{array}{l}\text { Kepuasan } \\
\text { nasabah }\end{array}$ & 2. & $\begin{array}{l}\text { pelayanan yang diberikan } \\
\text { sesuai dengan harapan } \\
\text { pelayanan di bni syariah } \\
\text { layak direkomendasikan } \\
\text { kepada orang lain } \\
\text { senang dengan doa } \\
\text { kebaikan yang diberikan } \\
\text { setiap nasabah bertransaksi } \\
\text { penggunaan produk secara } \\
\text { berkelanjutan }\end{array}$ \\
\hline
\end{tabular}

\subsection{Kerangka Pemikiran}

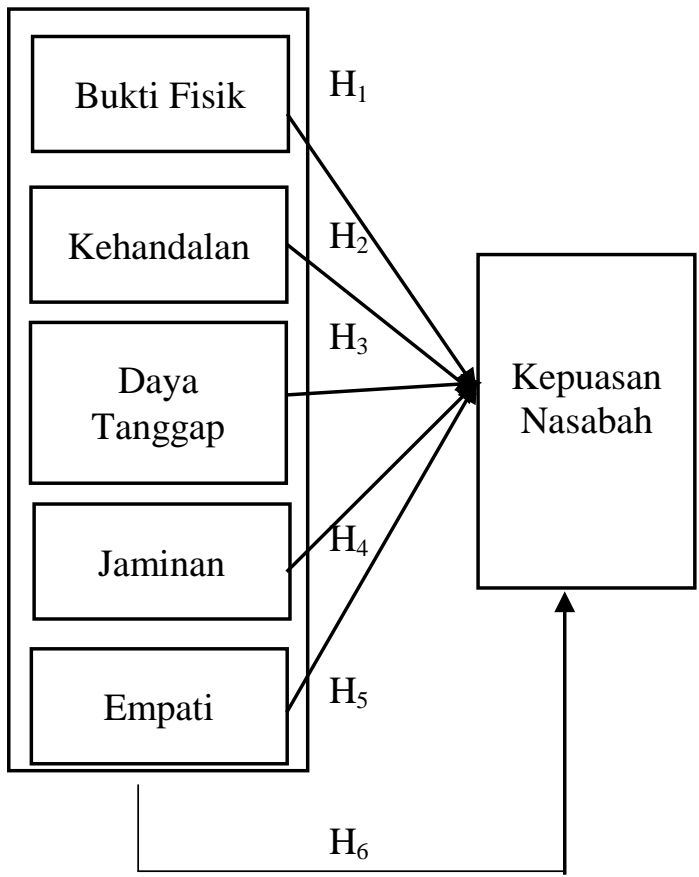

\section{Gambar 1. Kerangka Pemikiran}

\subsection{Hipotesis}

Hubungan antar variabel dalam penelitian ini memiliki hipotesis sebagai berikut:

$\mathrm{H}_{0}=$ Tidak ada pengaruh variabel kualitas pelayanan terhadap kepuasan nasabah di BNI Syariah KCP Kartini Depok.

$\mathrm{H}_{1}=$ Ada pengaruh variabel bukti fisik terhadap kepuasan nasabah di BNI Syariah KCP Kartini Depok.

$\mathrm{H}_{2}=$ Ada pengaruh variabel kehandalan terhadap kepuasan nasabah di BNI Syariah KCP Kartini Depok.

$\mathrm{H}_{3}=$ Ada pengaruh variabel Daya Tanggap terhadap kepuasan nasabah di BNI Syariah KCP Kartini Depok.

$\mathrm{H}_{4}=$ Ada pengaruh variabel asuransi terhadap kepuasan nasabah di BNI Syrariah KCP Kartini Depok.

$\mathrm{H}_{5}=$ Ada pengaruh variabel empati terhadap kepuasan nasabah di BNI Syariah KCP Kartini Depok.

$\mathrm{H}_{6}=$ Ada pengaruh variabel kualita pelayanan terhadap kepuasan nasabah di BNI Syariah KCP Kartini Depok.

\section{METODE PENELITIAN}

\subsection{Jenis Penelitian}

Jenis penelitian yang akan digunakan dalam penelitian ini adalah jenis penelitian kausalitas. Jenis penelitian kausalitas digunakan untuk membuktikan hubungan antara sebab dan akibat beberapa variabel pada situasi yang direcanakan.

\subsection{Lokasi, Objek dan Waktu Penelitian}

Penelitian ini dilakukan di kantor BNI Syariah KCP Kartini-Depok di Ruko Kartini Grande No. 64 G Kelurahan Pancoran Mas Kota Depok. Dengan objek penelitian adalah seluruh nasabah BNI Syariah KCP KartiniDepok yang memiliki rekening di BNI Syariah KCP Kartini. Waktu penelitian bulan Mei-Juni 2019.

\subsection{Populasi dan Sampel}

Populasi dalam penelitian ini adalah semua nasabah yang memiliki rekening dan bertransaksi di Bank BNI Syariah KCP Kartini. Jumlah nasabah sampai pada waktu penelitian adalah 1.734 nasabah.

Penentuan jumlah minimal sampel dalam penelitian ini menggunakan rumus Slovin dengan taraf kepercayaan $90 \%$ (tingkat error sebesar 0.10) adalah sebagai berikut : 
Dimana :

$$
n=\frac{N}{1+N(e)^{2}}
$$

$\mathrm{N}$ : Jumlah Populasi

$\mathrm{n}$ : Jumlah Sampel

$e$ : Taraf kesalahan (pada penelitian taraf kesalahan yang digunakan berkisar 0.10)

Maka perhitungan jumlah sampel minimal adalah sebagai berikut :

$n=\frac{1,734}{1+1,734(0.10)^{2}}$

$n=\frac{1,734}{18.43}=94.54$

Dari hasil tersebut peneliti memutuskan untuk mengambil sampel sebanyak 100 nasabah Bank BNI Syariah KCP KartiniDepok.

Teknik pengambilan sampel mengunakan purposive sampling, dimana sampel diambil bila sempel merupakan nasabah yang memiliki rekening di Bank Syariah KCP Kartini dan melakukan transaksi minimal 1 kali dalam satu bulan. Pengumpulan data menggunakan kuisioner yang telah dilakukan uji validasi dan uji reabilitas

\subsection{Uji Analisis Regresi Linier Berganda}

Model regresi linier berganda yang digunakan dalam penelitian pengaruh kualitas pelayanan frontliner terhadap kepuasan nasabah Bank BNI Syariah KCP Kartini Depok adalah:

$$
\begin{aligned}
Y= & a+b_{1} X_{1}+b_{2} X_{2}+b_{3} X_{3}+b_{4} X_{4} \\
& +b_{5} X_{5}+e
\end{aligned}
$$

Dimana:

$\mathrm{Y}=$ Kepuasan Nasabah

$\mathrm{a}=$ Konstanta

$\mathrm{b}_{1}=$ Koefisien regresi Wujud Fisik

$\mathrm{b}_{2}=$ Koefisien regresi Kehandalan

$\mathrm{b}_{3}=$ Koefisien regresi Daya Tanggap

$\mathrm{b}_{4}=$ Koefisien regresi Jaminan $\mathrm{b}_{5}=$ Koefisien regresi Empati

$\mathrm{X}_{1}=$ Variabel Wujud Fisik

$\mathrm{X}_{2}=$ Variabel Kehandalan

$\mathrm{X}_{3}=$ Variabel Daya Tanggap

$\mathrm{X}_{4}=$ Variabel Jaminan

$\mathrm{X}_{5}=$ Variabel Empati

$e=$ error

\section{HASIL DAN PEMBAHASAN}

Salah satu cabang BNI Syariah yang berdiri adalah BNI Syariah KCP Kartini Depok. KCP Kartini ini berdiri sejak tahun 2011. Awal mula berdirinya KCP Kartini ini bernama BNI Syariah Mikro Depok. Pada saat itu, KCP ini lebih fokus terhadap pembiayaan mikro dan di bawah naungan Divisi Bisnis Mikro pada Kantor Pusat BNI Syariah. Namun pada bulan November 2018 terjadi transformasi dari unit mikro menjadi unit reguler dan berubah nama menjadi KCP Kartini. Ketika sudah berubah menjadi KCP BNI Syariah reguler , KCP Kartini pun melakukan penjualan produk yang lebih luas dibandingkan pada saat masih menjadi divisi mikro. KCP Kartini Depok ini berlokasi di Jl Raya Citayam Ruko Kartini Grande No 46 G Pancoran Mas Kota Depok, dan KCP Kartini menginduk pada KC Tanah Sareal Bogor.

Adapun Struktur organisasi yang terdapat pada BNI Syariah KCP Kartini Depok terdiri dari : Sub Branch Manager, Operational Service Head, Sales Asistant, Processing And Collection Assistant, Direct Sales, Customer Services, Teller, Operational And Support Assistant

\subsection{Karakteristik Resaponden \\ 4.1.1 Jenis Kelamin}

Sebagian besar data responden nasabah BNI Syariah KCP Kartini Depok adalah wanita. Hal ini dapat dilihat dari 100 responden jumlah nasabah wanita mendominasi yaitu sebanyak 73 nasabah dan responden pria sebanyak 27 nasabah. 
Tabel 3. Jenis Kelamin Responden

\begin{tabular}{|l|c|r|}
\hline Jenis Kelamin & Frekuensi & Persen \\
\hline Laki-laki & 27 & $27 \%$ \\
\hline Perempuan & 73 & $73 \%$ \\
\hline
\end{tabular}

\subsubsection{Usia}

Usia responden Bank BNI Syariah KCP Kartini Depok banyaknya direntang usia 21-40 tahun sebanyak 97\%.

Tabel 4. Usia Responden

\begin{tabular}{|c|c|c|}
\hline Usia (tahun) & Frekuensi & Persen \\
\hline$<20$ & 2 & $2 \%$ \\
\hline $21-30$ & 44 & $44 \%$ \\
\hline $31-40$ & 49 & $49 \%$ \\
\hline $41-50$ & 5 & $5 \%$ \\
\hline$>50$ & 0 & $0 \%$ \\
\hline
\end{tabular}

\subsubsection{Pendidikan}

Pendidikan responden Bank BNI Syariah KCP Kartini Depok paling banyak berpendidikan diploma/sarjana sebesar $77 \%$.

Tabel 5. Pendidikan Responden

\begin{tabular}{|l|c|c|}
\hline \multicolumn{1}{|c|}{ Pendidikan } & Frekuensi & Persen \\
\hline SD/SMP/SMA & 3 & $3 \%$ \\
\hline Diploma/Sarjana & 78 & $78 \%$ \\
\hline Pascasarjana & 12 & $12 \%$ \\
\hline Liannya & 7 & $7 \%$ \\
\hline
\end{tabular}

\subsubsection{Pekerjaan}

Pekerjaan responden Bank BNI Syariah KCP Kartini Depok paling banyak adalah pegawai swasta sebesar $63 \%$.

Tabel 6. Pekerjaan Responden

\begin{tabular}{|l|c|c|}
\hline \multicolumn{1}{|c|}{ Pendidikan } & Frekuensi & Persen \\
\hline Pelajar/Mahasiswa & 2 & $5 \%$ \\
\hline PNS & 5 & $5 \%$ \\
\hline Pegawai swasta & 63 & $63 \%$ \\
\hline Wiraswasta & 14 & $14 \%$ \\
\hline Lainnya & 16 & $16 \%$ \\
\hline
\end{tabular}

\subsubsection{Pendapatan}

Pendapatan responden Bank BNI Syariah KCP Kartini Depok paling besar sekitar Rp 3.500.000 - 5.500.000 sebanyak $45 \%$.

Tabel 7. Pekerjaan Responden

\begin{tabular}{|l|c|c|}
\hline \multicolumn{1}{|c|}{ Pendidikan } & Frekuensi & Persen \\
\hline < Rp 3.5 Juta & 28 & $28 \%$ \\
\hline Rp 3,5-5,5 Juta & 45 & $45 \%$ \\
\hline Rp 5,5-7,5 Juta & 21 & $21 \%$ \\
\hline$>$ Rp 7,5 Juta & 6 & $6 \%$ \\
\hline
\end{tabular}

\subsubsection{Sumber Mengenal BRI Syariah}

Responden mengenal BRI Syariah lewat televisi, relasi, koran, majalah, brosur dan dari karyawan Bank BRI Syariah sendiri. Sumber pengenalan Bank BRI Syariah paling banyak dari relasi sebanyak $56 \%$.

Tabel 8. Pekerjaan Responden

\begin{tabular}{|l|c|c|}
\hline \multicolumn{1}{|c|}{ Pendidikan } & Frekuensi & Persen \\
\hline Televisi & 18 & $18 \%$ \\
\hline Relasi & 56 & $56 \%$ \\
\hline Koran/Majalah & 14 & $14 \%$ \\
\hline Brosur & 5 & $5 \%$ \\
\hline Staf BRI Syariah & 7 & $7 \%$ \\
\hline
\end{tabular}

\subsection{Uji Validitas}

Uji Validitas berguna untuk mengetahui kevalidan atau kesesuaian angket yang digunakan oleh peneliti untuk memperoleh data dari responden atau sampel penelitian. Uji validitas menggunakan uji pearson correlation dengan prinsip mengkorelasikan atau menghubungkan antara masing-masing skor item atau soal dengan skor total yang diperoleh dari jawaban responden atau kuesioner dengan tingkat kepercayaan 90\%. Nilai $r$ tabel $(98 ; 0.1)$ adalah 0.165 . Kriteria pengmbilan keputusan adalah sebagai berikut:

1. Jika $\mathrm{r}$ hitung $>\mathrm{r}$ tabel, maka pernyataan dikatakan valid.

2. Jika $\mathrm{r}$ hitung $\leq \mathrm{r}$ tabel, maka pernyataan dikatakan tidak valid. 
Tabel 9. Hasil Uji Validitas

\begin{tabular}{|c|c|c|c|c|}
\hline Variabel & Pertanyaan & R Hitung & R Tabel & Keterangan \\
\hline \multirow{4}{*}{$\begin{array}{l}\text { Wujud Fisik } \\
\text { (Tangibel) }\end{array}$} & 1 & 0.593 & 0.165 & Valid \\
\hline & 2 & 0.821 & 0.165 & Valid \\
\hline & 3 & 0.502 & 0.165 & Valid \\
\hline & 4 & 0.657 & 0.165 & Valid \\
\hline \multirow{4}{*}{$\begin{array}{l}\text { Kehandalan } \\
\text { (Reliability) }\end{array}$} & 5 & 0.704 & 0.165 & Valid \\
\hline & 6 & 0.615 & 0.165 & Valid \\
\hline & 7 & 0.565 & 0.165 & Valid \\
\hline & 8 & 0.7097 & 0.165 & Valid \\
\hline \multirow{3}{*}{$\begin{array}{c}\text { Daya } \\
\text { Tanggap } \\
\text { (Responsive) }\end{array}$} & 9 & 0.732 & 0.165 & Valid \\
\hline & 10 & 0.700 & 0.165 & Valid \\
\hline & 11 & 0.637 & 0.165 & Valid \\
\hline \multirow{3}{*}{$\begin{array}{c}\text { Jaminan } \\
\text { (Assurance) }\end{array}$} & 12 & 0.669 & 0.165 & Valid \\
\hline & 13 & 0.645 & 0.165 & Valid \\
\hline & 14 & 0.757 & 0.165 & Valid \\
\hline \multirow{3}{*}{$\begin{array}{c}\text { Empati } \\
\text { (Emphaty) }\end{array}$} & 15 & 0.637 & 0.165 & Valid \\
\hline & 16 & 0.439 & 0.165 & Valid \\
\hline & 17 & 0.628 & 0.165 & Valid \\
\hline \multirow{4}{*}{$\begin{array}{c}\text { Kepuasan } \\
\text { Nasabah }\end{array}$} & 18 & 0.492 & 0.165 & Valid \\
\hline & 19 & 0.624 & 0.165 & Valid \\
\hline & 20 & 0.587 & 0.165 & Valid \\
\hline & 21 & 0.611 & 0.165 & Valid \\
\hline
\end{tabular}

Sumber: data diolah (2019)

Berdasarkan hasil uji validitas terdapat 21 pertanyaan kuisioner memiliki nilai $\mathrm{r}$ hitung $>\mathrm{r}$ tabel. Sehingga seluruh pertanyaan dinyatakan valid dan kuisioner dapat digunakan dalam penelitian.

\subsection{Uji Reliabilitas}

Reabilitas adalah uji untuk mengukur tingkat kehandalan kuesioner. Uji reliabilitas yang dipakai dengan menggunakan alpha cronbach dengan ketentuan:

1. Jika Alpha > dari 0,6 maka dapat dikatakan reliabel.

2. Jika Alpha $\leq$ dari 0.6 maka dapat dikatakan tidak reliable

Dari Tabel 4 dapat dilihat nilai alpha cronbach sebesar 0.928 lebih besar dari 0.60 sehingga butir-butir pertanyaan dalam kuisioner merupakan butir pertanyaan yang handal atau realibel.
Tabel 10. Hasil Uji Reliabilitas

\begin{tabular}{|r|r|r|}
\hline $\begin{array}{c}\text { Cronbach's } \\
\text { Alpha }\end{array}$ & $\begin{array}{c}\text { Cronbach's Alpha Based } \\
\text { on Standardized } \\
\text { Items }\end{array}$ & $\begin{array}{c}\mathrm{N} \text { of } \\
\text { Items }\end{array}$ \\
\hline .928 & .930 & 21 \\
\hline
\end{tabular}

Sumber: data diolah (2019)

\subsection{Uji Normalitas}

Uji normalitas bertujuan untuk mengetahui normal atau tidaknya suatu distribusi data. Pengujian tersebut dilakukan dengan menggunakan uji normalitas histogram.

Berdasarkan hasil uji normalitas dapat dilihat grafik histogram (Gambar 2) memberikan pola distribusi seperti lonceng dengan luas sebelah kanan dan kiri sama besar, sehingga data berdistribusi normal.

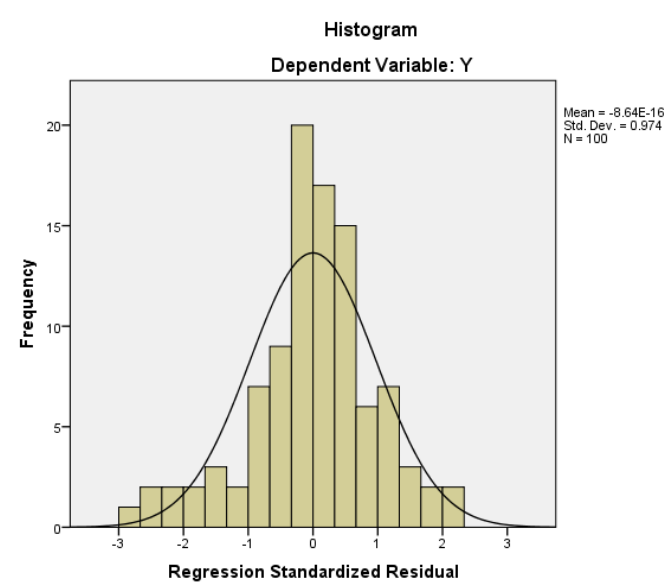

Gambar 2. Uji Normalitas dengan
Histogram

4.5 Uji Multikolinearitas

Tujuan digunakan uji multikolinearitas adalah untuk menguji apakah dalam model regresi ditemukan adanya korelasi antar variable-variabel independent. Model regresi yang baik seharusnya tidak terjadi gejala multikolinearitas, 
Tabel 11. Hasil Uji Multikolinearitas

\begin{tabular}{|c|c|c|c|c|c|c|c|c|}
\hline & \multirow[t]{2}{*}{ Model } & \multicolumn{2}{|c|}{$\begin{array}{c}\text { Unstandardized } \\
\text { Coefficients }\end{array}$} & \multirow{2}{*}{$\begin{array}{c}\begin{array}{c}\text { Standardized } \\
\text { Coefficients }\end{array} \\
\text { Beta }\end{array}$} & \multirow[b]{2}{*}{$\mathrm{t}$} & \multirow[b]{2}{*}{ Sig. } & \multicolumn{2}{|c|}{ Collinearity Statistics } \\
\hline & & B & Std. Error & & & & Tolerance & VIF \\
\hline & (Costant) & 2.090 & 1.925 & & 1.086 & .280 & & \\
\hline & $\mathrm{X} 1$ & .208 & .144 & .165 & 1.447 & .151 & .471 & 2.125 \\
\hline & $\mathrm{X} 2$ & .052 & .134 & .044 & .386 & .700 & .472 & 2.119 \\
\hline & $\mathrm{X} 3$ & .197 & .135 & .152 & 1.453 & .150 & .557 & 1.795 \\
\hline & $\mathrm{X} 4$ & .027 & .144 & .021 & .187 & .852 & .485 & 2.060 \\
\hline & $\mathrm{X} 5$ & .591 & .128 & .437 & 4.602 & .000 & .676 & 1.479 \\
\hline
\end{tabular}

Sumber: data diolah (2019)

Kriteria pengambilan keputusan dalam uji multikoineritas adalah nilai tolerance lebih besar dari 0.10 dan nilai VIF kurang dari 10. Pada hasil Tabel 4 diatas dapat dilihat hasil dari tolerance pada semua variabel lebih besar dari 0.10 dan nilai VIF kurang dari 10, Maka dapat disimpulkan bahwa tidak terjadi gejala multikolinearitas dalam model regresi.

\subsection{Uji Heteroskesdastisitas}

Uji heteroskesdastisitas digunakan untuk mengetahui ada atau tidaknya ketidaksamaan residual untuk semua pengamatan dalam model regresi. Pengujian dapat dilakukan menggunakan grafik scatterplot.

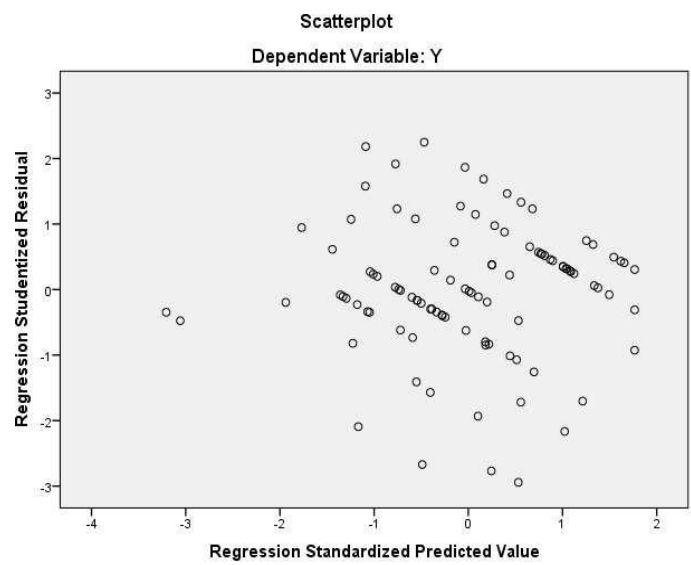

Gambar 3. Hasil Uji Heteroskedastisitas

Dari gambar diatas dapat dilihat titik titik data menyebar diatas dan dibawah atau disekitar angka 0 , dengan demikian dapat disimpulkan bahwa tidak terjadi masalah heteroskedastisitas.

\subsection{Uji Analisis Regresi Linier Berganda}

Hasil dari pengolahan regresi linier berganda dapat dilihat pada Tabel 5. Nilai parameter yang telah diestimasi dapat dilihat pada kolom $\mathrm{B}$, nilai tersebut menujukkan perubahan variabel independent terhadap variabel dependen.

Tabel 12. Analisis Regresi Linier Berganda

\begin{tabular}{|c|c|c|c|c|c|c|}
\hline & \multirow[t]{2}{*}{ Model } & \multicolumn{2}{|c|}{$\begin{array}{l}\text { Unstandardized } \\
\text { Coefficients }\end{array}$} & \multirow{2}{*}{$\begin{array}{c}\begin{array}{c}\text { Standardized } \\
\text { Coefficients }\end{array} \\
\text { Beta }\end{array}$} & \multirow[b]{2}{*}{$\mathrm{t}$} & \multirow[b]{2}{*}{ Sig. } \\
\hline & & B & Std. Error & & & \\
\hline \multirow[t]{6}{*}{1} & (Costant) & 2.090 & 1.925 & & 1.086 & .280 \\
\hline & $\mathrm{X} 1$ & .208 & .144 & .165 & 1.447 & .151 \\
\hline & $\mathrm{X} 2$ & .052 & .134 & .044 & .386 & .700 \\
\hline & $\mathrm{X} 3$ & .197 & .135 & .152 & 1.453 & .150 \\
\hline & $\mathrm{X} 4$ & .027 & .144 & .021 & .187 & .852 \\
\hline & $\mathrm{X} 5$ & .591 & .128 & .437 & 4.602 & .000 \\
\hline
\end{tabular}

Sumber: data diolah (2019)

Dari tabel tersebut diatas menunjukan hasil persamaan regresi berganda sebagai berikut :

$Y=2.090+0.208 X_{1}+0.052 X_{2}+0.197 X_{3}$ $+0.027 X_{4}+0.591 X_{5}$

1. Dari tabel diatas dapat dilihat nilai bukti fisik 0.208 artinya jika variabel kehandalan, daya tanggap, jaminan, dan empati dianggap tetap dan BNI Syariah KCP Kartini meningkatkan kualitas pada variabel bukti fisik, maka setiap peningkatan variabel wujud fisik per satu satuan akan meningkatkan kepuasan nasabah sebesar 0.208.

2. Nilai Kehandalan 0.052 artinya jika variabel wujud fisik, daya tanggap, jaminan, dan empati dianggap tetap dan BNI Syariah KCP Kartini meningkatkan kualitas pada variabel kehandalan, maka setiap peningkatan variabel kehandalan per satu satuan akan meningkatkan kepuasan nasabah sebesar 0.052 .

3. Nilai Daya Tanggap 0.197 artinya jika variabel wujud fisik, kehandalan, 
jaminan, dan empati dianggap tetap dan BNI Syariah KCP Kartini meningkatkan kualitas pada variabel daya tanggap, maka setiap peningkatan variabel daya tanggap per satu satuan akan meningkatkan kepuasan nasabah sebesar 0.197.

4. Nilai Jaminan 0.027 artinya jika variabel wujud fisik, kehandalan,daya tanggap, dan empati dianggap tetap dan BNI Syariah KCP Kartini meningkatkan kualitas pada variabel jaminan, maka setiap peningkatan variabel jaminan per satu satuan akan meningkatkan kepuasan nasabah sebesar 0.027.

5. Nilai Empati $=0.591$ artinya jika variabel wujud fisik, kehandalan,daya tanggap, dan jaminan dianggap tetap dan BNI Syariah KCP Kartini meningkatkan kualitas pada variabel empati, maka setiap peningkatan variabel empati per satu satuan akan meningkatkan kepuasan nasabah sebesar 0.591 .

Berdasarkan dari hasil regresi berganda tersebut, menunjukan bahwa semua variabel bernilai positif yang artinya semua variabel wujud fisik, kehandalan, daya tanggap, jaminan, dan empati berpengaruh positif terhadap kepuasan nasabah.

\subsection{Uji t}

Uji $t$ parsial bertujuan untuk mengetahui apakah variabel independent secara parsial berpengaruh terhadap variabel dependen. Adapun dasar dalam pengambilan keputusan uji $\mathrm{t}$ dilakukan berdasarkan perbandingan nilai dari nilai t-hitung dengan nilai t-tabel. variabel independent secara parsial berpengaruh terhadap variabel dependen bila nilai t-hitung $>\mathrm{t}$-tabel. Nilai ttabel $(94 ; 0.10)$ adalah 1.661.
Tabel 13. Hasil Uji t

\begin{tabular}{|l|c|c|c|}
\hline \multicolumn{1}{|c|}{ Variabel } & T-Hit & T-Tab & Ket \\
\hline Bukti fisik & 1.447 & 1.661 & Terima Ho \\
\hline Kehandalan & 0.386 & 1.661 & Terima Ho \\
\hline Daya tanggap & 1.453 & 1.661 & Terima Ho \\
\hline Jaminan & 0.187 & 1.661 & Terima Ho \\
\hline Empati & 4.602 & 1.661 & Tolak Ho \\
\hline
\end{tabular}

Sumber: data diolah (2019)

Berdasarkan uji t yang dilakukan dapat disimpulkan bahwa hanya variabel empati yang berpengaruh terhadap kepuasan nasabah, dimana t hitung (4.602) lebih besar dari t tabel (1.661).

\subsection{Uji F}

Uji $F$ digunakan untuk mengetahui secara simultan pengaruh vaiabel independen terhadap variabel dependen. Pengambilan keputusan dilakukan berdasarkan perbandingan nilai F-hitung dengan F-tabel. Bila F-hitung > F-tabel, maka secara simultan kualitas pelayanan frontliner berpengaruh terhadap kepuasan nasabah Bank BNI Syariah KCP Kartini Depok.

Tabel 14. Hasil Uji F

\begin{tabular}{|c|c|c|c|c|c|}
\hline Model & $\begin{array}{l}\text { Sum of } \\
\text { Squares }\end{array}$ & $\mathrm{df}$ & $\begin{array}{l}\text { Mean } \\
\text { Square }\end{array}$ & $\mathrm{F}$ & Sig. \\
\hline 1 Regression & 194.180 & 5 & 38.836 & 14.001 & $.000^{6}$ \\
\hline Residual & 260.730 & 94 & 2.774 & & \\
\hline Total & 454.910 & 99 & & & \\
\hline
\end{tabular}

Sumber: data diolah (2019)

Berdasarkan data pada Tabel 9 di atas diketahui $\mathrm{F}$ hitung sebesar 14.001 sedangkan nilai $\mathrm{F}$ table $(94,5 ; 0.10)$ sebesar 1.91. Berdasarkan data tersebut diketahui bahwa $\mathrm{F}$ hitung > F tabel sehingga Ho ditolak dan $\mathrm{Ha}$ diterima, artinya secara bersama-sama bukti fisik, kehandalan, daya tanggap, jaminan dan empati berpengaruh terhadap kepuasan nasabah. Sehingga hal ini menunjukkan bahwa hipotesis yang diajukan diterima, dengan demikian PT Bank BNI Syariah KCP Kartini dapat meningkatkan kualitas pelayanan untuk 
dapat meningkatkan kepuasan nasabah.

\subsection{Uji Koefisien Determinasi $\left(\mathbf{R}^{2}\right)$}

Uji koefisien determinasi digunakan untuk mengetahui seberapa besar variabel bebas memiliki pengaruh terhadap variabel terikat. Nilai koefisien determinasi $\mathrm{R}^{2}$ digunakan adjusted $R$ square untuk mengukur seberapa besar variasi variabel independent dapat menjelaskan variabel dependen yang diteliti.

Tabel 15. Hasil Uji Koefisien Determinasi

\begin{tabular}{|l|r|r|r|r|}
\hline Model & \multicolumn{1}{|c|}{$\mathrm{R}$} & R Square & $\begin{array}{c}\text { Adjusted } \\
\text { R Square }\end{array}$ & $\begin{array}{c}\text { Std. Error } \\
\text { of the } \\
\text { Estimate }\end{array}$ \\
\hline 1 & $.653^{\mathrm{3}}$ & .427 & .396 & 1.665 \\
\hline
\end{tabular}

Sumber: data diolah (2019)

Berdasarkan pada tabel diatas ini menunjukan bahwa nilai adjusted $R$ square adalah 0.396 atau $39.6 \%$. Hal ini berarti bahwa variasi variabel independent yaitu wujud fisik, kehandalan, daya tanggap, jaminan dan empati mampu menjelaskan variabel dependen yaitu kepuasan nasabah sebesar $39.6 \%$ dan selebihnya $60.4 \%$ dijelaskan oleh variabel lain yang tidak termasuk dalam analisa atau penelitian regresi ini.

\section{KESIMPULAN DAN SARAN}

\subsection{Kesimpulan}

Adapun Kesimpulan yang dapat diambil dari hasil penelitian tentang "Pengaruh Kualitas Pelayanan Frontliner Terhadap Kepuasan Nasabah Pada Bank BNI Syariah KCP Kartini” adalah sebagai berikut :

1. Analisis Regresi Linier Berganda

Berdasarkan analisis regresi linier berganda menunjukan hasil persamaan sebagai berikut :

$\mathrm{Y}=2.090+0.208 \mathrm{X}_{1}+0.052 \mathrm{X}_{2}+$ $0.197 X_{3}+0.027 X_{4}+0.591 X_{5}$

2. Uji t
Berdasarkan uji t yang dilakukan dapat disimpulkan bahwa hanya variabel Empati yang berpengaruh terhadap kepuasan nasabah.

3. Uji F

Berdasarkan uji f kualitas pelayanan secara simultan berpengaruh tehadap kepuasan nasabah,

4. Uji Koefisien Determinasi

Variasi variabel independent yaitu wujud fisik, kehandalan, daya tanggap, asuransi dan empati mampu menjelaskan variabel dependen yaitu kepuasan nasabah sebesar 39.6\%

\subsection{Saran}

Berdasarkan hasil penelitian maka saran yang diberikan adalah Bank BNI Syariah KCP Kartini harus lebih meningkatkan variabel empati untuk dapat meningkatkan kepuasan nasabah dan menjadi nasabah yang loyal pada Bank BNI Syariah KCP Kartini Depok.

\section{DAFTAR PUSTAKA}

Crosby, P.B. 1979. Quality is Free: The Art of Marking Quality Certain. New. York: McGraw-Hill.

Deming, W. Edwards. 1982. Guide to Quality Control. Cambirdge: Massachussetts Institute Of Technology

Gaspersz, Vincent. 1997. Manajemen Kualitas. Jakarta: PT. Gramedia Pustaka Utama

Juran, J. M. 1962. Quality control handbook. New York: McGraw-Hill.

Kottler. 2004. Manajemen Pemasaran (Terjemahan Jilid II). PT Indeks, Jakarta.

Schneider, B., dan Bowen, D.E. 1985. Employee and customer perceptions of service in bank: Replication and extension. Journal of Applied Psychology, 70, p.423-433.

Zeithaml, V.A., Parasuraman, A., and Berry, L.L, 1990. Delivering quality service - 
balancing customer perceptions and expectations., New York: The Free Press. 